NBER WORKING PAPER SERIES

\title{
DID DIVIDENDS INCREASE IMMEDIATELY AFTER THE 2003 REDUCTION IN TAX RATES?
}

\author{
Jennifer L. Blouin \\ Jana Smith Raedy \\ Douglas A. Shackelford \\ Working Paper 10301 \\ http://www.nber.org/papers/w10301
NATIONAL BUREAU OF ECONOMIC RESEARCH 1050 Massachusetts Avenue
Cambridge, MA 02138
February 2004

The views expressed herein are those of the authors and not necessarily those of the National Bureau of Economic Research.

(C)2004 by Jennifer L. Blouin, Jana Smith Raedy, and Douglas A. Shackelford. All rights reserved. Short sections of text, not to exceed two paragraphs, may be quoted without explicit permission provided that full credit, including (C) notice, is given to the source. 
Did Dividends Increase Immediately After the 2003 Reduction in Tax Rates?

Jennifer L. Blouin, Jana Smith Raedy, and Douglas A. Shackelford

NBER Working Paper No. 10301

February 2004

JEL No. H24, G35

\section{$\underline{\text { ABSTRACT }}$}

The Jobs and Growth Tax Relief Reconciliation Act of 2003 reduces the maximum statutory personal tax rate on dividends from 38.1 percent to 15 percent. This study analyzes dividend declarations in the quarter following passage. Aggregate dividends rose by 9 percent when boards of directors first met following enactment. Consistent with the dividend changes being taxmotivated, they are increasing in the percentage of the firm held by individuals. Dividend changes also increased with insider ownership, consistent with managers acting in their own interests. However, these results are limited primarily to firms that made large, special dividends. We find little evidence of an increase in regular, quarterly dividend payments.

Jennifer L. Blouin

The Wharton School

University of Pennsylvania

1315 Steinberg Hall-Dietrich Hall

Philadelphia, PA 19104

blouin@wharton.upenn.edu

Jana Smith Raedy

Kenan-Flagler Business School

University of North Carolina

CB\#3490, McColl Building

Chapel Hill, NC 27599-3490

jana_raedy@unc.edu

Douglas A. Shackelford

Kenan-Flagler Business School

University of North Carolina

CB\#3490, McColl Building

Chapel Hill, NC 27599-3490

and NBER

doug_shack@unc.edu 


\section{The Initial Impact of the 2003 Reduction in the Dividend Tax Rate}

\section{Introduction}

On May 28, 2003, President George W. Bush signed the Jobs and Growth Tax Relief Reconciliation Act of 2003 (2003 Act). Among other provisions, the legislation reduces the maximum statutory personal tax rate on dividends from 38.1 percent to 15 percent, the largest decrease in the dividend tax rate in U.S. history. Proponents of the legislation asserted that dividend taxes were a binding constraint on dividend payments and that reducing the rate would boost dividends. Dividends, however, have been in long decline, and the temporary nature of this legislation (it expires in 2009) raises doubts about its efficacy in reversing this trend. The purpose of this paper is to determine the impact of the legislation on dividend payments.

Understanding the extent to which dividend taxes impede corporate distributions is central to our understanding of the firm. ${ }^{1}$ Scholars have long contended that the tax asymmetry accorded dividends (i.e., shareholders pay tax on non-deductible corporate distributions) affects capital structure, investments, and security valuations (Modigliani and Miller, 1958, 1963; Miller, 1977; Miller and Modigliani 1961; Scholes et al. 2002; among many others). Recently, this asymmetry has been linked to optimal debt levels (Graham 2000, 2003, Kemsley and Nissim, 2002), pension assets, (Frank 2002), trust-preferred stock (Engel, Erickson, and Maydew, 1999), the growth in employee stock option compensation (Lambert, Lanen and Larcker 1989), organizational structure (Guenther 1992, Gentry 1994) and corporate governance (La Porta et al. 2000).

However, despite the importance of dividend taxation, little is known about the elasticity of dividends payments to shareholder taxes. The reason is that at least three identification problems have thwarted empirical tests. One, major changes in dividend tax rates are unusual. Two, changes in

\footnotetext{
${ }^{1}$ Some might consider a test of the impact of individual taxes on dividend policy premature, given the lack of consensus in the literature about the reasons why companies pay dividends (see discussions in Easterbrook 1984 and Bhattacharya 1979, among many others). However, as we wait for a resolution of the dividend puzzle, it seems prudent to examine the 2003 Act for any possible insights into our understanding of firms and their investors.
} 
dividend taxes usually have coincided with other major tax policy changes. Three, dividend tax rates have always been identical to the rates on other sources of ordinary income, such as interest, rents, royalties and, since 1981, wages. ${ }^{2}$ The last two problems have made it particularly difficult to isolate the effects of dividend tax rate changes on corporate distributions.

The 2003 Act at least partially overcomes all three of these limitations. First, the magnitude of the dividend tax rate change in the 2003 Act is unprecedented. Second, the 2003 Act does not undertake fundamental reform that widely affects the tax code. Its genesis was dividend tax reduction and remained so throughout legislative deliberations. Third, dividends are no longer taxed at the same rate as other forms of ordinary income, facilitating isolation of the economic impact of a change in dividend tax rates. Consequently, the 2003 legislation provides an opportunity for scholars to test the impact of dividend taxes and thus address questions of capital structure, organizational structure (e.g., corporate versus flowthrough entity), corporate governance, and investor clienteles.

This paper begins this investigation of the 2003 Act by asking whether boards of directors increased dividends when they had their first opportunities following enactment, specifically during the first six months following passage. Although more quarters of data will be needed before we can fully understand the total impact of the 2003 dividend tax rate reduction on corporate distributions, our analysis of the first two quarters following enactment is not an unreasonably short period to anticipate a response.

The reason is that we would anticipate a more rapid response to this legislation than normally observed with tax changes. ${ }^{3}$ Unlike most legislative changes, which are permanent, the dividend tax reduction is temporary, reverting to 35 percent in 2009. Moreover, the reversion could be as early as

\footnotetext{
${ }^{2}$ None of the seven changes in dividend tax rates over the last quarter-century provides favorable conditions for isolating the responsiveness of dividends to dividend tax rates. In 1982, as part of a broad tax reduction during the first Reagan Administration, the tax rate on dividends, as well as all other ordinary income, fell from 70 percent to 50 percent. During the sweeping 1986 tax reform, ordinary rates tumbled to 38.5 percent in 1987 and 28 percent in 1988. In 1991, the rate for dividends and all other ordinary income rose 3 percentage points to 31 percent. Two years later the tax rate on all ordinary income increased to 39.6 percent. Recently, all ordinary income tax rates have slipped slightly with a 0.5 percent decline to 39.1 percent in 2001 and another 0.5 percent reduction to 38.6 percent in 2002 .

${ }^{3}$ Besides the urgency created by the temporary nature of the legislation, the purported purpose of the legislation (economic stimulus) depended critically on an immediate response to the rate reduction. If dividend policy did not change during 2003 that does not rule out the possibility that dividend payments may increase eventually, but it does raise doubts about the efficacy of dividend tax relief as a means of immediate economic stimulus.
} 
2005 for many shareholders. Senator John Kerry has promised to restore the higher dividend tax rate for individuals in the two highest tax brackets if he is elected President in November 2004. Consequently, procrastination may cost shareholders the opportunity to extract dividends from corporations at a historically low tax cost.

The proposition that the largest decrease ever in dividend tax rates would substantially boost dividend payments is relatively straightforward. ${ }^{4}$ It assumes that dividend taxes have been a binding constraint on shareholder distributions. Freed of the constraint, dividends rise to a new equilibrium. This “old view" logic underlies President Bush's assertion at the signing that "The bill also allows for dividend income to be taxed at a lower rate. This will encourage more companies to pay dividends..." The U.S. House of Representatives Ways and Means Committee's Report on Jobs and Growth Tax Relief Reconciliation Act of 2003 adds that the dividend tax reduction will decrease the tax incentive to retain earnings, implying that the 2003 Act would boost dividend payments.

Concurrent research by Chetty and Saez (2004) provides preliminary support for these claims. Examining longitudinal data from 1980 to the first quarter of 2004, Chetty and Saez (2004) report that the fraction of firms paying regular and special dividends rose after enactment. They also claim that many firms that were already paying dividends substantially increased their payments. Unfortunately, Chetty and Saez (2004) are unable to reject at conventional levels that the amount of the dividend increases occurred by chance, a failure they attribute to the volatility of the aggregate dividends series and outliers in their analysis.

Moreover, as they acknowledge, their study cannot rule out a spurious relation between dividends and taxes. This concern is heightened because they report that the increase in the percentage of firms paying and initiating regular dividends began as early as January 2003. Although it is possible that changes in dividend policy were tax-motivated in early 2003, it seems unlikely. President Bush first

\footnotetext{
${ }^{4}$ An alternative scenario would predict that dividend payments would actually fall after a rate reduction. This alternative assumes that shareholders demand the same after-tax dividends from their shareholdings, regardless of their dividend taxes. Thus, a cut in dividend taxes reduces the amount of dividends needed to produce the required after-tax cash.
} 
proposed exempting dividends from taxation (as opposed to a rate reduction) in January. Controversial deliberations raged for five months, and several times it appeared likely that no bill would pass. Finally, five months after the President's original proposal, Congress chose to lower dividend taxes, not eliminate them. Given the uncertainty about whether the bill would pass and, if so, the effective date of any changes, non-tax factors (e.g., an improving economy and corporate governance pressure to distribute excess cash) likely contributed more to early 2003 dividend increases than changes in expectations about future dividend tax rates. If so, these same non-tax factors may have been the reason that dividends increased in the second half of 2003 following enactment.

Employing an alternative approach, this paper collaborates many of the findings in Chetty and Saez (2004). After examining the dividend declarations of 1,477 firms around enactment, we too conclude that more firms are issuing regular and special dividends after tax rates fell. However, we can demonstrate a statistically significant increase in both regular and special dividend payments following enactment. We also show that share repurchases declined after enactment, consistent with buybacks being a substitute for dividends, which became more attractive with a rate reduction.

To rule out the possibility that nontax factors are driving the recent rise in dividends, we attempt to provide direct evidence linking the 2003 changes in tax rates and dividend increases. The logic behind these tests is simple: If reductions in personal taxes caused dividends to surge, then we should expect to find a positive correlation between dividend increases and the extent to which the firms are owned by individuals, the only beneficiaries of the legislation. Unfortunately, we fail to find such a relation.

However, we do find some evidence of a positive association between insider ownership and dividend increases. This would suggest that the mere presence of large number of individual investors in the shareholder group was insufficient to alter dividend policy. Rather having the firm owned heavily by managers and other key insiders, who benefited from the lower tax rates, was needed to boost dividends.

Although we recognize that these tests suffer from the usual measurement problems facing empirical archival work, without this compelling link between dividend changes and shareholder tax benefits, we are hesitant to conclude that tax rates cut caused dividends to increase. We are particularly 
cautious because the economy improved during the same period that the legislation took effect and the business press was regularly reporting that the market was looking to dividends, rather than earnings, to assess firm quality. In short, it appears possible that the increases in dividends that we observe reflect business fundamentals and changes in investor sentiment more than tax cuts for individual investors. Moreover, as detailed in the next section, there are a several reasons why dividends might not increase in response to the reduction in the dividend tax rate.

The paper develops as follows: The next section develops the study's testable hypotheses. Sections 3 and 4 discuss tests of the impact of the legislation on regular, quarterly dividends. Section 5 investigates the impact on special, one-time dividends. Section 6 reports results from tests of share repurchases. Concluding remarks follow.

\section{Hypothesis Development}

This section begins by detailing seven reasons why the 2003 Act might not have resulted in increased dividend payments. Some of them lead directly to testable hypotheses. Most do not, but are discussed here to provide a complete picture of the impediments faced by firms considering whether to increase their dividend payout following enactment of the 2003 Act.

The first reason is that dividends have fallen into disfavor. Fama and French (2001) document that the number of dividend payers has been halved over the last two decades. In fact, only 70 percent of the Standard and Poor's 500 were paying dividends at the end of 2002, down from 94 percent in 1980 (Opdyke, J., Wall Street Journal, October 7, 2003). DeAngelo, et al. (2003) add that dividends are largely concentrated among a few firms, with just 25 companies accounting for over half of the total dollar amount of dividends in the U.S. in 2000.

Moreover, it is unclear the extent to which dividend taxes account for the declining popularity of dividends. Both the dividend tax rate and the relative tax advantage of long-term capital gains (i.e., the spread between long-term capital gains tax rates and dividend tax rates) were less before the 2003 rate 
reductions than they were 20-50 years ago when dividend yields were much greater. Therefore, it is not obvious that reducing the dividend tax would suddenly result in a surge in dividend payments.

Furthermore, even if firms were inclined to reconsider dividends in light of their individual shareholders' enhanced demand for dividends, it is not clear that companies would initiate or increase their dividends. Unprofitable, overleveraged, and cash-constrained firms are in no position to pay dividends, regardless of the dividend tax rate. Likewise, growth firms, a large sector of the economy, have always been unlikely to pay dividends (Lintner, 1956).

Moreover, nowadays, many stable, profitable firms with substantial cash balances pay no dividends (e.g., Intel, Dell, Cisco and, until January 2003, Microsoft). Managers at these firms apparently have believed that shareholder value is maximized by retaining cash within the firm or using it to buy back stock, rather than distributing cash to shareholders in the form of dividends. As a result, it is unclear that changing dividend tax policy is a lever that will affect corporate distributions to their shareholders.

In fact, many corporations claim that dividend taxes are irrelevant in their dividend policy. In a survey of corporate payout policy, Brav et al. (2003) report that 69 percent of CFOs state that the elimination of dividend taxation would definitely not or probably not affect their firms' dividend decisions. For example, in response to President Bush's original dividend exclusion proposal in January 2003 (which would have eliminated any dividend taxes for many companies' shareholders), International Paper's CEO, John Dillon, said that even if dividends were tax-exempt, it would "not change our behavior with respect to dividends.” (McKinnon, J., Wall Street Journal, January 17, 2003).

The second reason that the 2003 Act might not materially increase dividends is that changes in dividends alter employee stock option compensation. Dividends reduce the value of stock options because the distribution of cash reduces the net assets, and thus share price, of the firm; however, those dividends are not distributed to option holders. Thus, increasing dividends may require granting additional stock options to employees and/or shifting to other forms of compensation. The costs of restructuring existing compensation arrangements and increasing potential principal-agent problems by 
undermining the incentives provided by stock options may exceed the benefits of lower dividend taxes on individuals. If so, some firms may opt to leave their dividend policy unaltered.

The third reason we might not observe a large response to the 2003 Act relates to the alternative minimum tax (AMT), which taxpayers pay if it exceeds their regular tax. Because the AMT applies to individuals with reasonably high levels of income (typically taxable income between $\$ 100,000$ and $\$ 500,000)$, the AMT is most likely the relevant tax for many individual shareholders. The legislation reduced the maximum statutory tax rate on dividends to 15 percent for both regular and alternative minimum tax purposes. However, since the maximum statutory tax rate on dividends was already capped at 28 percent for the AMT, shareholders facing the AMT enjoy less benefit from the 2003 Act than individuals facing the regular tax, who may have been taxed at Federal rates as high as 38.1 percent on their dividends.

Furthermore, since the regular tax reduction for dividends exceeds the AMT tax reduction for dividends (because of the differences in statutory rates), the 2003 Act will cause some individuals, who have avoided the AMT in the past, to face the AMT in the future (because it exceeds their now-reduced regular tax). As a result of facing the AMT (the calculation of which is beyond the scope of this paper), these individuals will now lose some non-dividend tax preferences. Consequently, their marginal tax rates on dividends can exceed 15 percent. In other words, because the AMT disallows the exclusion or deductibility of various tax preferences permitted under the regular tax, the net effect of a shift from regular tax to AMT can be marginal tax rates on dividends that exceed 15 percent. Thus, the benefits of the 2003 Act are further mitigated, lessening any demand for increased dividends.

The fourth reason that the dividend tax cut may not affect corporate payouts is that the dividend tax rate reduction only benefits shares held by individuals or flow-through entities, e.g., mutual funds, partnerships, trusts, $\mathrm{S}$ corporations, or limited liability corporations that pass dividend income through to investors' personal tax returns. Moreover, these shareholders must hold shares for at least 60 days in the 120-day period beginning 60 days before the ex-dividend date for the reduced rates to apply.

Shareholders with shorter trading horizons, tax-exempt organizations, tax-deferred accounts (e.g., 
qualified retirement plans, including IRAs and 401(k)), corporations and foreigners are unaffected by the legislation. Thus, companies held by unaffected shareholders have no incentive to alter their dividend policy.

Stated in alternative form, the first hypothesis predicts that:

$\mathrm{H}_{1}$ : Increases in dividend payments following the 2003 Act were increasing in the percentage of the payer's stock held by individual investors.

Rejecting the null hypothesis that changes in dividend payments are unrelated to individual ownership would provide strong evidence that corporations took shareholder tax preferences into account when they set their dividend policy following the 2003 Act. This evidence would be particularly compelling because it is difficult to construct an alternative non-tax explanation of why firms with heavy individual stock ownership increased their dividend declarations following the dividend tax rate reduction more than companies with large institutional ownership.

On the other hand, we will fail to reject the null if firms ignore their shareholders' tax preferences in setting dividend policy. Prior literature is mixed on this question. Barclay, Holderness and Sheehan (2003) report that dividends seldom change following the substitution of a new large blockholder with different tax status. Conversely, Perez-Gonzalez' (2003) reports that dividend policy is heavily influenced by the tax status of the largest shareholder. Lie and Lie's (1999) add that managers consider shareholders' tax considerations when deciding between dividends and share repurchases. Furthermore, concurrent work by Hsich and Wang (2004) show that tax incentives of insiders affect corporate payout choices, corroborating the findings in this study.

The next two reasons motivate the second hypothesis, which concerns the type of dividend paid — regular, quarterly dividends versus special dividends. One, firms are reluctant to increase their regular, quarterly dividends since the increase likely will have to be rescinded (Healy and Palepu, 1988). By increasing their quarterly dividends in response to the 2003 tax change, firms greatly increase the probability that they will have to cut their quarterly dividends in the future (or accept a suboptimal distribution policy) because the rate reduction is temporary. 
The dividend tax rate will revert to 35 percent on January 1, 2009. ${ }^{5}$ Furthermore, John Kerry has promised to rescind the 2003 dividend tax rate reduction for individuals in the highest two tax brackets, if he is elected President in November, 2004. ${ }^{6}$ Since many individual shareholders fall in these upper brackets, restoration of the higher tax rates for them likely would substantially undermine the support for corporate distributions in the form of dividends. Given this uncertainty about future dividend tax rates and because the market is known to respond negatively to reductions and omissions of dividend payments (Brav et al. 2003), it seems reasonable that many companies would forgo the opportunity provided by the 2003 Act to increase their regular, quarterly dividends to avoid the probable rescission.

Two, regular, quarterly dividends may alleviate asymmetric information costs by conveying information about future earnings to the market. If so, tax-motivated adjustments in the quarterly dividends could distort the intended signal. The information costs associated with investors' inability to distinguish between increases that are tax-induced and increases that are profitability-induced may exceed the benefits of reduced shareholder taxes under the new law. Thus, it is possible that managers would intentionally not alter their regular, quarterly dividend policy to maintain credibility with the market.

These two reasons — costs associated with rescission and asymmetric information — can be avoided by declaring a special dividend rather than altering the firm's regular quarterly distribution. This leads to the second hypothesis:

$\mathrm{H}_{2}$ : Firms increased their special dividends following the 2003 Act.

The final reason that firms may not increase dividends is that among the profitable companies who could distribute profits to shareholders and would consider their shareholders' tax preferences in those distributions, the tax-efficient distribution continues to be share repurchases. Although the

\footnotetext{
${ }^{5}$ Some may assume that sunset provisions, such as the reversion of the dividend tax rate to 35 percent, will be automatically extended before they take effect. Gale (2003), however, makes a compelling case that the costs of extending all the various sunset provisions currently in the law is probably fiscally impracticable. He estimates that removing all the sunsets in the tax code would reduce government revenue by almost $\$ 2$ trillion over the next decade.

${ }^{6}$ Individuals in the highest two brackets (maximum statutory rates of 33 percent and 35 percent) receive 38 percent of all the dividend income reported in the United States.
} 
maximum statutory tax rate on dividends now equals the top rate on long-term capital gains (which was reduced from 20 percent to 15 percent in the 2003 Act), dividends continue to be taxed disadvantageously compared with capital gains for at least four reasons. One, dividends accelerate the tax payment that could be deferred until the stock is sold (or fully avoided if held until the shareholder dies). Two, unlike dividends, shareholders can time the sale of an investment and thus pay the resulting capital gain tax when the shareholder's marginal tax rate is lowest. Three, with capital gains a portion of the proceeds is treated as a return of basis and thus goes untaxed. Conversely, basis cannot be used to avoid dividend income. $^{7}$ Four, since only $\$ 3,000$ of capital losses (net of capital gains) can be deducted each year, capital gains, unlike dividends, enable individuals to accelerate utilization of their pool of capital losses, an important consideration for many individuals following the downturn in the equity markets from 2000 to 2002.

However, it is possible that the rate changes in the 2003 Act shifted the balance toward dividends, i.e., share repurchases continue to dominate dividends, but not by as much as they did before the legislation. If so, because dividends have been found to be substitutes for share repurchases (see Miller and Modigliani, 1961; Grullon and Michaely, 2002; among others), we predict a decline in share repurchases following enactment. This leads to the third hypothesis:

$\mathrm{H}_{3}$ : Firms decreased their share repurchases following the 2003 Act.

\section{Empirical Approach}

This section of the paper describes the selection of our sample of 1,463 regular dividend-paying companies. It then details the tests conducted on these companies to determine whether corporate distributions increased following enactment of the 2003 Act. Further tests are conducted to determine whether the changes are correlated with the mix of individual and institutional shareholders.

\footnotetext{
${ }^{7}$ As an example, suppose a shareholder faces a choice between receiving $\$ 100$ in dividends and selling an investment, which he purchased for $\$ 25$, for $\$ 100$. In both cases, the shareholder has $\$ 100$ before taxes. With dividends, however, he pays $\$ 15$ in taxes $(100 * 15$ percent), leaving $\$ 85$ after-tax. With the sale, he pays $\$ 11.25$ $\left[(100-25)^{*} 15\right.$ percent) in taxes, leaving 88.75 after-tax. The $\$ 3.75$ (\$88.75-85) difference is one of timing. When the stock is finally sold, the basis will be recovered.
} 


\section{A. Sample}

The sample selection is designed to identify corporations that declared regular dividends during the first six months following the Congressional passage of the bill on May 23, 2003 or (for purposes of constructing a control sample) during the same period in 2002 . We draw the initial sample from the 14,258 dividend declarations representing 3,101 firms from the Center for Research in Security Prices (CRSP) between May 23, 2003 and November 22, 2003 and/or the same period in 2002. To exclude noncorporate distributions on common stock, we require firms to have CRSP share code 11 (eliminates 1,151 firms). ${ }^{8}$ Since we are examining changes in firm payout policy over time, we require our firms to be in existence from October 1, 2001 through December 31, 2003 (eliminates 195 firms). We limit our sample to regular quarterly cash dividends (CRSP distribution code 1232) for firms that did not change fiscal year-ends during the period (eliminates 226 firms). Firms also must have Compustat earnings information available for the quarter immediately preceding the dividend declaration date as well as our proxies for individual holdings (eliminates 66 firms). This leaves a final sample of 1,463 companies.

Table 1 provides descriptive information for the 1,463 sample firms. The mean (median) company has a market capitalization of $\$ 4.8(\$ 0.6)$ billion with total assets of $\$ 12.5$ (\$1.3) billion. Its mean (median) sales are $\$ 1.0$ (\$0.1) billion, on which it earns $\$ 73(\$ 7)$ million.

The 1,463 sample firms are concentrated in financial services and manufacturing. 615 firms (42 percent of the sample) are in SIC 6 (finance, insurance and real estate); 459 companies (31 percent) are manufacturers (SIC 2 and 3). The remaining companies are mostly in SIC 4 (transportation and utilities) with 137 firms (9 percent) and SIC 5 (trade) with 115 corporations ( 8 percent).

\section{B. Comparing Regular, Quarterly Dividend Payments Before and After the 2003 Act}

To determine the initial impact of the 2003 Act on regular, quarterly dividend payments, we compare dividends declarations during the first two quarters following passage of the bill with previous

\footnotetext{
${ }^{8}$ Share code 11 indicates that dividends are declared on ordinary common shares. This restriction results in the exclusion of ADRs, REITS, closed-end funds and partnership units that face dividend taxation unaffected by the 2003 Act.
} 
quarters. (Assuming boards of directors meet at least once every three months to declare dividends, this investigation period ensures that we captured the boards' first two opportunities to alter dividends following the rate reduction.) Specifically, we compare the dividends declared from May 23, 2003 (the first working day following Congressional approval of the 2003 Act) to November 22, 2003 with the dividend payments declared during the five quarters ending May 22, 2003. Since Congressional passage occurred late at night on May 22, 2003, corporate boards meeting on the 23rd would have known that their shareholders would face a maximum statutory rate of only 15 percent and presumably could have confidently adjusted dividends upward beginning on that date. Thus, although the bill did not become law until the President signed it on May 28, 2003, it should have been clear to corporate officials, beginning on May 23, 2003, that the bill would become law because the President had strongly supported dividend tax relief throughout the legislative process.

Table 2, Panel A provides summary statistics for the regular, quarterly dividend declarations of the 1,463 sample firms. We find that 1,402 firms declared dividends during the quarter immediately following passage of the bill (May 23-August 22, 2003). In the subsequent quarter (August 23, 2003November 22, 2003) 18 more firms declared dividends for an average of 1,411 firms during the two quarters following enactment. This compares with an average of 1,310 firms in the same two quarters a year earlier. We can reject at the 0.01 level that this 8 percent increase in frequency is by chance.

Over the seven-quarter period, total dividends rose from $\$ 36.0$ billion to $\$ 41.6$ billion, a 16 percent increase. Total dividend declarations rose every quarter with the largest jump around enactment, swelling \$2.9 billion increase (8 percent) from the quarter ended May 22, 2003 to the quarter ended August 22, 2003. This compares with a $\$ 1.8$ billion cumulative increase ( 5 percent) over the five quarters before enactment and a $\$ 0.9$ billion rise ( 2 percent) in the second quarter following enactment.

The mean (median) dividend declaration rose from 14.5 (11.0) cents per share in the quarter ended May 22, 2002 to 15.3 (12.0) cents per share in the quarter ended November 22, 2003. The mean (median) dividend payment across the two quarters comprising the post-enactment period is $15.2(0.120)$ cents per share, compared with 14.6 (11.4) cents per share in the five quarters comprising the pre- 
enactment period. This aggregate pre/post mean (median) difference is significant at the $0.05(0.01)$ level.

We further test whether dividend declarations increased over the investigation period by comparing within-firm dividend changes. For example, when we subtract each firm's dividend declaration in the quarter ended May 22, 2003 (the quarter before enactment) from its dividend announcement in the quarter ended August 22, 2003 (the first quarter after enactment), we find that the mean increase is 0.7 cents per share, which is significant at the 0.001 level. As seen in the last column of Panel A, this mean difference exceeds the mean difference for all other adjacent quarters. Two other increases are highly significant: 0.4 cents per share (between the two quarters immediately after enactment) and 0.3 cents per share (between the two quarters immediately before enactment).

Table 2, Panel B repeats this analysis for the 1,280 firms that paid regular dividends in each of the seven quarters. These 1,280 firms paid almost all of the dividends in the U.S. For example, in the quarter ended November 22, 2003, these 1,280 firms paid all, but $\$ 1$ billion, (98 percent) of the dividends in the full sample of 1,463 firms. Not surprisingly, we find that the inferences drawn from Panel A above hold with this sample of continual dividend payers. Briefly, declarations rose every quarter with the largest increase ( $\$ 2.5$ billion or 7 percent) around enactment. The mean (median) dividend payment across the two quarters comprising the post-enactment period is 15.7 (13.0) cents per share, compared with 14.8 (12.0) cents per share in the five quarters comprising the pre-enactment period. We can reject that this mean (median) difference is random at the 0.01 (0.01) level. The last column of Panel B confirms that mean of the within-firm differences in dividend declarations is greatest around enactment $(0.5$ cents per share) although significantly positive as early as the quarter ending February 22, 2003.

We conclude from Table 2 that the largest dividend increases were immediately following enactment. However, dividends were rising before enactment and continued rising in the second quarter after enactment. This leaves us to conclude that non-tax factors (such as an improving economy) likely played a role in boosting dividends. The unresolved question is the extent to which taxes assisted in the dividend increases. 
These initial findings are consistent with more firms paying dividends as well as more dividends being paid after the passage of the 2003 Act. Although this implies that the tax rate reduction boosted dividend payments, we cannot rule out the possibility that dividends have been on an upward trend or that dividends increased in this period for reasons unrelated to taxes, such as improved earnings, stronger cash flow, or reduced growth opportunities.

Table 3 reports summary statistics from a regression intended to control for these possible nontax effects. The analysis is conducted on the full sample of 1,463 firms at the firm-quarter level. Not all firms declared dividends every quarter. Thus, we are left with 9,448 regular dividend declarations across the seven quarters. We have missing data for 277 declarations, leaving us with 9,171 firm-quarters to examine.

The dependent variable is the dividends per share declared in the quarter (DPS). The explanatory variables are earnings per share $(E P S)$, intended to capture the firm's profitability; free cash flow $(F C F)$, a measure of the firm's payout capacity; and the market-to-book ratio $(M T B)$, designed to control for growth opportunities for which firms might employ excess cash. Both EPS and FCF are lagged one quarter. We add a categorical variable (POST), which equals one for declarations after enactment. We will interpret a positive coefficient on POST as consistent with dividends increasing following enactment.

Panel A provides descriptive statistics. The mean (median) dividend per share is 15 (12) cents. Mean (median) EPS is 39 (35) cents per share. Mean and median FCF are negative. Mean (median) MTB is 2.23 (1.82).

Panel B presents the regression results. ${ }^{9}$ The first column shows the results from an ordinary least squares approach. The coefficient on EPS is positive, as expected, consistent with dividends rising with firms' profits. No other control variables are significantly different from zero. The coefficient on POST is positive and significant at conventional levels. This finding is consistent with regular, quarterly

\footnotetext{
${ }^{9}$ Conclusions are unaltered when the equations are estimated using firm fixed effects. The POST coefficient is always positive and significant at the 0.001 level.
} 
dividends being greater after enactment than they were before, conditional on several possible non-tax effects.

The second column repeats the process using rank regressions. Results hold. The POST coefficient is positive and significant at the 0.01 level. The next two columns report the results from repeating the first two estimations using the reduced sample of 1,280 firms that paid dividends in every quarter. Inferences are qualitatively unchanged. The POST coefficient remains positive and highly significant.

The final column uses a logistic estimation process. It expands the sample to include quarters in which no dividends were declared and redefines the dependent variable as a categorical variable which equals one if a dividend is paid in the period. The POST coefficient is positive and highly significant, consistent with an increased frequency in dividend payments after enactment.

We infer from these results that regular, quarterly dividends increased in both amounts and frequency following enactment of the 2003 dividend tax rate reduction. This conclusion holds even after taking into account the apparent boost to dividends arising from increased profitability.

\section{C. $\quad$ Linking Dividends to Shareholders}

We continue our regression analysis to test the hypothesis that dividend increases are greatest in those companies whose shareholders benefit most from the rate reduction. That is, companies held predominantly by individuals directly through their own taxable accounts or through conduits where the taxation of the dividends lands ultimately on an individual tax return. These conduits include partnerships, S corporations, limited liability corporations, and some trusts.

Documenting a link between dividend increases and the individual ownership (as broadly defined above) would provide particularly compelling evidence that the dividend increases are attributable to tax changes because it is difficult to construct a non-tax reason why dividends surged in the second half of 
2003 for companies held disproportionately by individuals. ${ }^{10}$ Conversely, if we fail to find a link between declarations and individual ownership, it remains feasible that the increase in dividend declarations is caused by omitted correlated variables (such as changes in expectations about future profitability).

The dependent variable is the dividends declared in period $\mathrm{t}\left(D I V_{\mathrm{t}}\right)$, where period $\mathrm{t}$ includes dates before and after enactment. The first control variable, which is designed to capture any stickiness in dividends, is the dividends declared in the prior period $\left(D I V_{\mathrm{t}-1}\right.$ or $\left.L A G D I V_{\mathrm{t}}\right)$. To capture variability in the source of dividends, we include earnings from the prior period t-1 $\left(E P S_{\mathrm{t}-1}\right) .{ }^{11}$ All three variables are expressed in per share amounts. ${ }^{12}$

Ideally, the key explanatory variable of interest would measure the change in dividend taxes experienced by the marginal investor as a result of the 2003 Act. If the marginal investor is an individual whose tax rate fell from 38.1 percent to 15 percent, then the measure would capture this 23.1 percentage point decline in dividend tax rates. If the marginal investor is a tax-deferred entity or a tax-exempt entity, then the 2003 rate reduction would have no effect on its dividend taxes.

Unfortunately, the marginal investor and his tax return are unobservable. Thus, the literature has turned to less precise measures to estimate the extent to which a firm's marginal investor is affected by personal tax changes. No one method has emerged as the standard. Perez-Gonzalez' (2003) uses the largest single shareholder to proxy for the dividend tax treatment of the marginal investor. Jin (2004) measures the extent to which the institutional investors are conduits that pass the taxation of the dividends to individuals. Ayers, et al. (2002, 2003), Blouin, et al. (2003), and Dhaliwal, et al. (2003) use 13-F filings to develop measures of the percentage of the firm held by individual shareholders.

\footnotetext{
${ }^{10}$ As an illustration of the difficulty of constructing an alternative hypothesis, imagine one based on stories in the business press that investors have become more focused on cash dividends than accounting earnings after Enron, WorldCom and similar debacles. If this is true, the shift to cash from profits should be greatest in companies with the most asymmetric information between managers and investors. One possible set of such companies are those with many, small individual shareholders. If so, it is feasible that a positive correlation could be detected between individual ownership and dividend increases, as predicted in this paper. However, since Enron, WorldCom and most of the financial collapses occurred in 2001 and early 2002, it is unclear why this shift in preferences to dividends did not occur until the summer of 2003. Also, we find some evidence that dividend hikes are increasing in insider ownership, which is contrary to the asymmetric information story. Also, it is unclear how paying a onetime, special dividend allays long-term concerns about information asymmetries.

${ }^{11}$ Conclusions are qualitatively unaltered if we use earnings from the current period, i.e., $\left(E P S_{\mathrm{t}}\right)$.

${ }^{12}$ Inferences are robust to scaling by total assets or share price.
} 
We follow this last group in developing two measures of individual ownership. IND is one less the percentage of shares that are held by institutional investors as reported in 13-F filings and collected by CDA/Spectrum, as of June 30, 2002. ${ }^{13}$ INSIDE is the percentage of shares held by insiders as measured by holdings of officers and directors as reported in Thomson Financial's Insider Filing Data. Obviously, this study's ability to link dividend changes to shareholder tax preferences rests critically on the usefulness of these measures to discriminate across firms.

The explanatory variables include the firm's dividend for the six months immediately preceding enactment divided by its stock price (DYIELD). This measure is designed to capture the capacity for dividend increases. Firms with high dividend yields presumably had less capacity to increase their dividends after enactment than firms paying little or no dividends.

We interact IND, INSIDE and DYIELD with a categorical variable (POST), which is one if the dividend was declared after enactment and zero otherwise. This recognizes the possibility that IND, INSIDE and DYIELD may have had different impacts on dividend declarations after enactment. A positive estimated regression coefficient on $P O S T^{*} I N D$ will be interpreted as evidence that dividend declarations after enactment of the 2003 Act were increasing in the level of individual ownership in the company. Since we are unaware of any non-tax reason that dividends should have risen with the percentage of stock held by individual investors during the summer of 2003, we will interpret a positive coefficient on $P O S T^{*} I N D$ as strong evidence that the 2003 rate reductions increased dividends. Likewise, a positive estimated regression on $P O S T^{*} I N S I D E$ will be interpreted as evidence that dividends increases were rising in the percentage of the firm owned by insiders.

$$
\begin{aligned}
& D I V_{i, t}=\beta_{0}+\beta_{1} L A G D I V_{i, t}+\beta_{2} \text { EPS }_{i, t-1}+\beta_{3 \mathrm{n}}(1+P O S T) *\left[\alpha_{0}+\alpha_{1} I N D_{i}+\alpha_{2} I N S I D E_{i}+\alpha_{3}\right. \\
& \left.\operatorname{DYIELD}_{i}\right]+ \text { CONTROLS }+\varepsilon_{i, t}
\end{aligned}
$$

\footnotetext{
${ }^{13}$ We intentionally chose individual ownership data from a date before Bush's original dividend exclusion proposal in January 2003 to avoid the possibility that clienteles began to shift in anticipation of a reduction in dividend tax burden. If we use post tax relief measures of individual ownership, we could erroneously infer that high individual ownership firms responded to the legislation by increasing dividends, when in actuality individuals simply bought disproportionately large numbers of shares in companies that were increasing their dividends.
} 
CONTROLS are intended in the model to capture other possible determinants of the level of dividends, such as industry, growth, risk, and size, which are presumed not to vary systematically with the change in dividend tax rates (and thus are not interacted with POST).

Rather than tabulate the results from estimating equation (1), we convert the levels expression in equation (1) to a changes model. Equation (1) produces two observations for every firm in the sample, one observation from before enactment and another from after enactment. Below in equation (2), we employ a changes model that yields one observation per firm. In short, we regress the change in a firm's dividends around enactment, while controlling for its changes in dividends around a similar period when tax rates did not change.

$$
\Delta D I V_{i}=\beta_{0}+\beta_{1} L A G \Delta D I V_{i}+\beta_{2} \Delta E P S_{i}+\beta_{3} I N D_{i}+\beta_{4} I N S I D E_{i}+\beta_{5} D Y I E L D_{i}+\varepsilon_{i, t}(2)
$$

$\Delta D I V_{i}$ is the difference between the dependent variables in firm i's post-enactment equation and firm i's pre-enactment equation. Similarly, $L A G \Delta D I V_{i}$ is the difference between firm i's post and pre-enactment measures of $L A G D I V$, and $\triangle E P S_{i}$ is the difference between earnings per share after and before the rate reduction. The other possible control variables (CONTROLS), which are constant before and after the legislative change (e.g., industry), drop from the regression model when the differences are taken. So does POST, since all observations now include data from both before and after enactment. This leaves the coefficient on IND (INSIDE) to capture the impact of individual (insider) ownership on changes in dividend payments and the coefficient on DYIELD to capture differential effects of capacity on dividend payments. A positive estimated regression coefficient on IND (INSIDE) will be interpreted as evidence that the increase in dividends following passage of the 2003 Act was increasing in the percentage of a firm owned by individuals (insiders).

\section{Descriptive Statistics and Univariate Results}

To estimate equation (2), we must define the pre and post enactment periods. We begin by defining the post-enactment period as the six months following enactment (May 23-November 22, 2003) 
and the pre-enactment period as the six months preceding enactment. (Below we repeat the analysis with a variety of pre and post periods.) Consequently, $\Delta D I V$ is dividends per share as declared from 5/23/03 to $11 / 22 / 03$ less dividends per share as declared from $11 / 23 / 02$ to $5 / 22 / 03$. LAG $\Delta D I V$ is dividends per share as declared from $11 / 23 / 02$ to 5/22/03 less dividends per share as declared from 5/23/02 to 11/22/02. $\triangle E P S$ is earnings per share as reported over the two quarters, $11 / 23 / 03$ to $5 / 22 / 03$, less earnings per share as reported over the two quarters, 5/23/02 to $11 / 22 / 02$.

Table 4, Panel A provides descriptive statistics for the regression variables. The dependent variable $(\triangle D I V)$ ranges from a 85 -cent decline in dividends per share to a 73 -cent increase in dividends per share with a mean increase of 2.2 cents per share. $L A G \Delta D I V$ has a mean value of 0.8 cents per share. Mean (median) lagged earnings ( $\triangle E P S)$ are 9.2 (3.0) cents per share. The mean and median quarterly dividend yields (DYIELD) are $1.2(1.1)$ percent.

IND and INSIDE are the two key explanatory variables for testing the hypothesis that shareholder mix affects dividends. Our estimate of individual ownership varies widely with the intraquartile ranging from 28.5 percent to 82.5 percent. Mean (median) IND is 52.4 (52.5) percent. Mean (median) INSIDE is 7.1 (2.6) percent.

Table 4, Panel B provides Pearson's and Spearman's rank correlation matrices for the regression variables. As expected, both correlations indicate that $\triangle D I V$ moves directly with lagged changes in dividends (LAG $\triangle D I V)$ and inversely with the correlated dividend yield (DYIELD). However, only one correlation involving the dependent variable and the two measures of individual ownership is significantly greater than zero. The Pearson correlation between $\triangle D I V$ and INSIDE is 0.07 .

\section{Regression Results}

A. Primary Tests

Table 5 reports the summary statistics from ordinary least squares estimation using the 1,463 sample firms. The first column reports the estimation results with IND in the regression; the second 
column with INSIDE in the regression; and the third with both measures of individual ownership. In all three columns, the coefficient on $L A G \triangle D I V$ is positive, as expected, consistent with dividends being sticky. The coefficient on $\triangle E P S$ is not significantly different from zero. Consistent with the univariate analysis, the coefficient on DYIELD is negative and highly significant, implying that firms with a high dividend yield before enactment responded with smaller increase in dividends.

The estimated regression coefficient on IND in the first column enables us to test whether dividends increased during the quarter following enactment of the 2003 Act (compared with the same period in 2002) in proportion to the percentage of the company held by individuals. Contrary to expectations, we find a negative estimated regression coefficient on $I N D$, though not significantly different from zero.

The second column tests whether dividend increases are linked to insider ownership. Here we find a positive and significant coefficient on INSIDE. The coefficient yields an economic interpretation. For example, the product of the INSIDE coefficient of 0.031 and the mean INSIDE of 0.071 is 0.2 cents of increased dividends per share or 10 percent of the mean value of $\triangle D I V$. Similarly, a firm moving within the intraquartile range (from 0.6 percent insider ownership to 8.1 percent insider ownership) would experience an increase in dividends of 0.2 cents per share or 10 percent of the mean value of $\Delta D I V$.

The third column includes both measures of individual ownership. Inferences are unchanged. The IND coefficient remains insignificant. The INSIDE coefficient increases to 0.036 with a $t$-statistic of 2.3 .

\section{B. Alternative Periods}

The inferences drawn above concerning the lack of relation between IND and changes in dividends is robust to alternative specifications of the pre and post-enactment periods. However, results are not robust for our finding of a positive relation between INSIDE and dividend increases. 
Table 6 reports the coefficients and t-statistics for $I N D$ and $I N S I D E$ under five different period specifications. Although not tabulated, the model contains the same control variables as above. IND and $I N S I D E$ are evaluated separately, i.e., the same estimates as the first two columns in Table 5. Contrary to expectations, the IND coefficient is always negative, though never significant.

The INSIDE coefficient is always positive. However, it is highly significant in only one specification (column 6), when the post-enactment period is the second quarter following enactment and the pre-enactment period is the last quarter before enactment. It is marginally significant (column 4), when the post-enactment period is the second quarter following enactment and the pre-enactment period is the first quarter after enactment. It is not significant in the other three specifications. We infer from these findings that including the second quarter after enactment is critical to finding a significant coefficient on INSIDE. This implies that it may have taken firms until the second quarter following enactment to begin adjusting their dividend policy to reflect the interest of insiders with large holdings.

We conclude that the evidence is mixed concerning whether dividend increases were greatest in those companies whose shareholders most benefited from the dividend tax rate reduction. We find no evidence that disproportionately large ownership by individual shareholders contributed to an increase in regular, quarterly dividends. We find conflicting evidence about the influence of insiders on changes to the firm's dividend policy. If we had detected a strong relation between changes in dividend payouts and individual and insider ownership, we would have interpreted such a result as providing strong evidence that the dividend increases were related to the tax rate reductions. Since we do not detect a strong relation, these results give us some pause.

\section{Special Dividends}

Regular, quarterly dividends may not have been the sole (or even primary) mechanism by which firms increased their distributions to shareholders following the rate reduction. If managers are concerned about the temporary nature of the rate reduction or the deleterious effects on signaling of a tax-motivated change in dividends, then firms may have opted for one-time, special dividends to distribute profits to 
shareholders while dividend tax rates were at a historical low. The next section reports results from tests designed to determine whether special dividends increased following enactment of the 2003 Act.

To assess whether special dividends rose after the dividend tax rate reduction, we repeated the procedures that were used to select the sample of regular, quarterly dividends in Section 3, but instead of regular dividends, we selected special, one-time dividends (CRSP distribution code 1272). Not surprisingly, special dividends occur much less often than regular, quarterly dividends with 62 firms declaring 84 special dividends over the seven-quarter investigation period (February 23, 2002 to November 22, 2003).

Table 7 shows the frequency of the special dividends across the seven quarters examined in the study. Fifty-three (63 percent) special dividends were paid in the two quarters after enactment. Using the non-parametric binomial test, we can reject at the 0.001 level that the increased frequency of special dividends following enactment occurred by chance.

To control for the possibility that the increase is attributable to non-tax factors, we analyze the 62 firms using a logistic estimation approach. The dependent variable is one in the firm-month when special dividends are paid and zero in all other months. The explanatory variables are the same as in Table 3: earnings per share $(E P S)$, free cash flow $(F C F)$, the market-to-book ratio $(M T B)$ and a categorical variable (POST) that equals one if the distribution is one of the 53 special dividends declared in the six months following enactment. Table 8, Panel A provides descriptive statistics for the explanatory variables. The first column in Table 8, Panel B shows that the coefficient on POST is positive and highly significant, consistent with the frequency of special dividends increasing after enactment (and the univariate test results reported above).

Next, we attempt to assess whether the amount paid per special dividend increased after enactment using regression analysis. Here the explanatory variables remain the same, while the dependent variable changes to special dividends per share $(S D)$, which ranges from one penny to $\$ 1.46$ with a mean (median) value of 58 (25) cents (reported in Table 8, Panel A). The second (third) column in Table 8, Panel B reports summary statistics using ordinary least squares (rank regressions). The variable 
of interest (POST) is not significantly different from zero in either regression, consistent with the amount of special dividends remaining constant after enactment. To summarize, the frequency of special dividends increased after enactment, but the amount paid per special dividend did not change.

Lastly, we investigate the extent to which individuals and insiders own the firms that pay special dividends. If special dividends dominate regular, quarterly dividends as an efficient means of distributing profits during a temporary reduction in tax rates, then individual shareholders, the sole beneficiaries of the rate reduction, should hold disproportionate interests in firms that issued special dividends after enactment. Table 9 reports the individual and insider ownership of firms paying special dividends before enactment, during the first quarter following enactment and during the subsequent quarter. It also lists the same measure for the 1,463 firms in the study that paid regular, quarterly dividends.

We find that individuals hold a greater percentage of the shares in companies that pay special dividends than they do in companies that pay regular, quarterly dividends. For example, individuals held 75 percent, on average, of the 22 firms that paid special dividends in the quarter immediately following enactment. This compares with 54 percent for firms paying regular, quarterly dividends. Reductions in the dividend tax rate, however, do not appear to account for the differences between individual investors in special dividend firms and individuals in regular, quarterly dividend firms. The reason is that individuals held large proportions of special dividend firms, both before and after enactment. For example, Table 9 shows that individuals held 86 percent of the 31 firms paying special dividends before enactment. In short, it appears that firms that pay special dividends have been and remain disproportionately owned by individual investors.

Insider ownership is greater in post-enactment special dividend-paying firms than pre-enactment special dividend-paying firms, though not significantly greater. ${ }^{14}$ In the two quarters after enactment, the

\footnotetext{
${ }^{14}$ Sun Hydraulics Corporation, which is held 38 percent by insiders, provides an example of an insider influencing a special dividend after enactment. In their July 10, 2003 announcement of a special dividend of $\$ 2.00$ per share, they specifically attributed the idea of the special dividend to their largest shareholder, Robert E. Koski, former chairman and current board member. Chairman Clyde Nixon said, "This distribution was proposed to the board of directors by the company's largest shareholder, as a way to provide a measure of liquidity and a return to the company's shareholders, in light of the stagnant market price of the company's stock over the past four years. Several factors
} 
mean (median) inside ownership of the special dividend-paying firms was 13.4 (8.4) percent. In the five quarters before enactment, the mean (median) inside ownership was 10.6 (3.1) percent of the outstanding shares. However, neither difference is significant, which may be attributable to the small sample size. Using a t-test of the means (a median test), we reject at the 22 (8) percent level that the inside ownership of special dividend-paying firms remained the same or fell following enactment.

\section{Share Repurchases}

We conclude this study with an initial analysis of the impact of the dividend tax legislation on share repurchases. Among others, Miller and Modigliani (1961), and Grullon and Michaely (2002) report that share repurchases are substitutes for dividends. If so, a tax-induced boost in dividend payments after enactment should have resulted in a reduction in share repurchases. This is true even though the capital gains tax rate, which applies to individuals who sell their shares in share buybacks, fell from 20 percent to 15 percent. The reason is that the dividend tax rate fell further than the capital gains tax rate.

To explore the possibility that share repurchases declined after enactment, we review the repurchase activity of the 1,477 different companies evaluated in the regular and special dividend analyses above. To avoid the possibility that firms delayed share repurchases once the President proposed dividend exemption in January 2003, we define the pre-enactment period as the seven months ending in December 2002 (i.e., June-December 2002). The post-enactment period is the same seven months one year later (i.e., June-December 2003). We find that share repurchases accounted for 29 percent of total distributions (defined as regular and special dividends plus repurchases) in the 2002 period, but only 19 percent in the 2003 period. We can reject at the 0.001 level that this slump in share repurchases after enactment occurred by chance. Furthermore, we find that 800 firms repurchased shares before enactment, but only 646 firms following enactment, a 19 percent decline. This decline in frequency is also significant at the 0.001 level.

influenced the board's decision: the recent reduction in the dividend tax rate to 15 percent, current low borrowing costs, and Sun's strong balance sheet and cash flow." 
To determine whether firms shifted from share repurchases to dividends, we further examined the 718 firms that changed both their regular dividends per share and their repurchases per share between 2002 and 2003. Of these firms, 93 percent increased their dividends. This is consistent with both an aversion to reducing dividends and a dramatic increase in regular dividends between 2002 and 2003. Conversely, only 36 percent increased their share repurchases. This is consistent with dividends following enactment partly substituting for share repurchases.

These initial findings suggest that the cut in the dividend tax rate reduced the need for share repurchases. However, there is an alternative explanation, which is beyond the scope of this paper. During 2003, many firms began to shift away from stock option compensation, slackening the demand for share repurchases. Thus, it is possible that nontax considerations contributed heavily to the observed decline in share repurchases.

\section{Conclusion}

The 2003 Act reduces the maximum statutory personal tax rate on dividend income from 38.1 percent to 15 percent, the largest reduction ever. Because dividend taxes are fundamental to capital and organizational structure, we anticipate this legislation providing a rich setting for studies in accounting, finance, and economics. We begin that inquiry by asking whether the legislation led to an immediate increase in dividend declarations. Many have long assumed that dividend taxes are an important binding constraint on corporate distributions. If so, we would expect at least some companies to avail themselves of the first opportunities to adjust their dividends upward to a new optimal level.

We find evidence that the legislation boosted regular and special dividends and dampened share repurchases. The firms in this study had increased their total regular dividends by $\$ 3.8$ billion (10 percent) six months after passage of the legislation. In those same six months, their special dividends were three-fold ( $\$ 1.2$ billion) the amount during the previous five quarters. Meanwhile, share repurchases were 25 percent less in the final seven months of 2003, compared with the same period a year earlier. In 
short, this paper presents strong evidence that regular and special dividends rose and share repurchases fell after Congress reduced the dividend tax rate.

However, it remains possible that the changes in distribution patterns relate to nontax influences, such as an expanding economy. Our attempts to rule out alternative explanations by linking changes in distributions to ownership in the companies by individuals, the sole beneficiaries of the 2003 tax legislation, is less compelling. In general, we find no evidence that companies held predominantly by individual investors, the only shareholders who benefited from the tax savings, were the ones changing their distribution patterns following enactment. However, we do find some evidence that companies held heavily by insiders were more likely to increase both regular and special dividends. 


\section{References}

Ayres, Benjamin, C. Bryan Cloyd, and John Robinson, 2002, The effect of shareholder-level dividend taxes on stock prices: Evidence from the Revenue Reconciliation Act of 1993, Accounting Review 77, 933-947.

Ayres, Benjamin, Craig Lefanowicz, and John Robinson, 2003, The effect of shareholder-level capital gains taxes on the structure of corporate acquisitions, Journal of Finance, forthcoming.

Barclay, Michael, Clifford Holderness, and Dennis Sheehan. 2003, Dividends and dominant shareholders, Working paper, University of Rochester.

Bhattacharya, Sudipto, 1979, Imperfect information, dividend policy, and "the bird in the hand" fallacy, Bell Journal of Economics 10, 259-270.

Blouin, Jennifer, Jana Raedy, and Douglas Shackelford, 2003, Capital gains taxes and equity trading: Empirical evidence, Journal of Accounting Research 41, 611-651.

Brav, Alon, John Graham, Campbell Harvey and Roni Michaely, 2003, Payout policy in the $21^{\text {st }}$ century, Working paper, Duke University.

Chetty, Raj and Emmanuel Saez, 2004, Do dividends respond to taxes? Preliminary evidence from the 2003 dividend tax cut? University of California at Berkeley and National Bureau of Economic Research working paper 10572.

DeAngelo, Harry, Linda DeAngelo, and Doug Skinner, 2003, Are dividends disappearing? Dividend concentration and the consolidation of earnings. Journal of Financial Economics, forthcoming.

Dhaliwal, Dan, Oliver Li, and Robert Trezevant, 2003, Is a dividend tax penalty incorporated into the return on a firm's common stock? Journal of Accounting and Economics 35, 155-178.

Easterbrook, Frank, 1984, Two agency-cost explanations of dividends. American Economic Review 74, 650-659.

Engle, Ellen, Merle Erickson, and Edward Maydew, 1999, Debt-equity hybrid securities, Journal of Accounting Research, 37, 249-274.

Fama, Eugene and Kenneth French, 2001, Disappearing dividends: Changing firm characteristics or lower propensity to pay, Journal of Financial Economics 60, 3-43.

Frank, Mary Margaret, 2002, The impact of taxes on corporate defined benefit plan asset allocation, Journal of Accounting Research 40, 1163-190.

Gale, William, "Sunsets in the tax code", Tax Notes, June 9,2003, 1553-1561.

Gentry, William, 1994, Taxes, financial decisions and organizational form: Evidence from publicly traded partnerships, Journal of Public Economics 53, 223-244.

Graham, John, 2000, How big are the tax benefits of debt, Journal of Finance 55, 1901-1941.

Graham, John, 2003, Taxes and corporate finance: A review, Review of Financial Studies, forthcoming. 
Grullon, Gustavo and Roni Michaely, 2002, Dividends, share repurchases and the substitution hypothesis. Journal of Finance LVII: 4, (August): 1649-1684.

Guenther, David, 1992, Taxes and organizational form: A comparison of corporations and master limited partnerships, Accounting Review 67, 17-45.

Healy, Paul and Krishna Palepu, 1988, Earnings information conveyed by dividend initiations and omissions, Journal of Financial Economics 21, 149-175.

Hsich, Jim and Quinghai Wang, 2004, Insiders' tax motivation and corporate payout policy, George Mason University and University of Wisconsin-Milwaukee working paper.

Jin, Li, 2004, Capital gain tax overhang and price pressure, Harvard Business School working paper.

Kemsley, Deen and Doron Nissim, 2002, Valuation of the debt-tax shield, Journal of Finance 57, 20452073.

La Porta, Rafael, Florencio Lopez-de-Silanes, Andrei Shleifer, and Robert Vishny, 2000, Agency problems and dividend policies around the world, Journal of Finance 55, 1-33.

Lambert, Richard, William Lanen and David Larcker, 1989, Executive stock option plans and corporate dividend policy, Journal of Financial and Quantitative Analysis 24, 409425 .

Lie, Erik and Heidi Lie, 1999, The role of personal taxes in corporate decision: An empirical analysis of share repurchases and dividends, Journal of Financial and Quantitative Analysis 34, 533-552.

Lintner, John, 1956, Distribution of incomes of corporations among dividends, retained earnings and taxes, American Economic Review 46, 97-113.

Miller, Merton, 1977, Debt and taxes, Journal of Finance 32, 261-275.

Miller, Merton, and Franco Modigliani, 1961, Dividend policy, growth and the valuation of shares, Journal of Business 34, 411-433.

Modigliani, Franco and Merton Miller, 1958, Cost of capital, corporation finance and the theory of investment, American Economic Review 48, 267-297.

Modigliani, Franco and Merton Miller, 1963, Corporate income taxes and the cost of capital: A correction, American Economic Review 53, 433-443.

Pérez-González, Francisco, 2003, Large shareholders and dividends: Evidence from U.S. tax reforms, Working paper, Columbia University.

Scholes, Myron, Mark Wolfson, Merle Erickson, Edward Maydew and Terry Shevlin, 2002, Taxes and Business Strategy $2^{\text {nd }}$ ed, (Prentice Hall, Upper Saddle River, NJ). 


\section{TABLE 1}

\section{Firm Characteristics for 1,463 Sample Firms Who Declared Dividends in the Six Months Following Enactment of the Jobs and Growth Tax Relief Reconciliation Act of 2003}

This table reports descriptive statistics for a sample of 1,463 U.S. firms. The data sample consists of all corporations reported by CRSP as declaring a regular quarterly dividend between February 23, 2002 and November 22, 2003 that have available information on the following variables: $\triangle D I V, L A G \triangle D I V, \triangle E P S, I N D$, and INSIDE. $\triangle D I V$ is dividends per share as declared from 5/23/03 to 11/22/03 less dividends per share as declared from 11/23/02 to $5 / 22 / 03$. LAG $\triangle D I V$ is dividends per share as declared from $11 / 23 / 02$ to $5 / 22 / 03$ less dividends per share as declared from $5 / 23 / 02$ to $11 / 22 / 02$. $\triangle E P S$ is quarterly earnings per share as reported during the period, $11 / 23 / 02$ to $5 / 22 / 03$ less quarterly earnings per share as reported during the period, 5/23/02 to 11/22/02 (Compustat item 69). DYIELD is annualized dividends in two quarters preceding 5/23/03, as a percentage of its share price on the declaration date. $I N D$ is one less the percentage of shares that are held by institutional investors as reported in $13-\mathrm{F}$ filings and collected by CDA/Spectrum. INSIDE is the percentage of shares held by insiders as measured by holdings of officers and directors as reported in Thomson Financial's Insider Filing Data. Market value of equity is the market value of common stock (Compustat item 14 times Compustat item 61). Total assets is the book value of assets (Compustat item 44). Sales is net sales (Compustat item 2). Net income is total net income (Compustat item 69). Debt-to-asset is the ratio of book value of debt (Compustat item 54) and total assets. Return on assets is the ratio of annualized net income in the quarter preceding 5/23/2003 divided by total assets in the same period. Return on equity is the ratio of annualized net income in the quarter preceding 5/23/2003 divided by book equity (Compustat item 60) in the same period. Share price is the closing share price (Compustat item 14) in dollars. Shares outstanding is (Compustat item 61) in millions. Except where noted all dollar figures are in millions and are as of the end of the first quarter in fiscal year ending 2003.

\begin{tabular}{|l|r|r|r|r|r|r|r|}
\hline & Mean & Median & Std Dev & \multicolumn{1}{c|}{ Min } & 25 $^{\text {th }}$ & \multicolumn{1}{|c|}{ 75th $^{\text {Max }}$} \\
\hline Market Value of Equity & 4,836 & 578 & 17,857 & 3 & 134 & 2,384 & 246,677 \\
\hline Total Assets & 12,534 & 1,280 & 62,260 & 7 & 459 & 4,510 & $1,187,035$ \\
\hline Sales & 1,022 & 144 & 3,450 & 0 & 22 & 618 & 57,224 \\
\hline Net Income & 73 & 7 & 280 & -480 & 1 & 39 & 4,324 \\
\hline Debt-to-Asset & 0.68 & 0.72 & 0.24 & 0.04 & 0.52 & 0.90 & 1.33 \\
\hline Return on Assets & 0.04 & 0.02 & 0.06 & -0.46 & 0.01 & 0.06 & 0.56 \\
\hline Return on Equity & 0.12 & 0.12 & 0.81 & -21.06 & 0.07 & 0.17 & 17.15 \\
\hline Share Price & 28 & 24 & 32 & 0 & 16 & 34 & 727 \\
\hline Shares Outstanding & 140 & 26 & 478 & 1 & 7 & 84 & 7,894 \\
\hline
\end{tabular}


TABLE 2

Regular Quarterly Dividends Per Share Declared

This table reports dividend per share descriptive statistics for a sample of 1,463 U.S. firms, described in Table 1. The data sample consists of all corporations reported by CRSP as declaring a regular quarterly dividend between February 23, 2002 and November $22,2003$.

\section{Panel $A$}

Dividend Declarations by Quarter for the full Sample of 1,463 Firms (expressed in cents)

\begin{tabular}{|c|c|c|c|c|c|c|c|c|c|c|}
\hline Declaration Periods & $\mathbf{N}$ & $\begin{array}{c}\text { Total \$ } \\
\text { (billions) }\end{array}$ & Mean & Median & Std Dev & Min & $25^{\text {th }}$ & $75^{\text {th }}$ & Max & $\begin{array}{c}\text { Mean of } \\
\text { Within-Firm } \\
\text { Increases }\end{array}$ \\
\hline August 23, 2003-November 22, 2003 & 1,420 & 41.6 & 15.3 & 12.0 & 12.7 & 0.5 & 6.7 & 20.0 & 145.0 & $0.4 *$ \\
\hline May 23, 2003-August 22, 2003 & 1,402 & 40.7 & 15.0 & 12.0 & 12.9 & 0.5 & 6.3 & 20.0 & 145.0 & $0.7 *$ \\
\hline February 23, 2003-May 22, 2003 & 1,358 & 37.8 & 14.7 & 12.0 & 12.7 & 0.5 & 6.0 & 19.1 & 145.0 & $0.3 *$ \\
\hline November 23, 2002-February 22, 2003 & 1,324 & 36.9 & 14.8 & 12.0 & 12.8 & 0.5 & 6.0 & 19.0 & 145.0 & 0.1 \\
\hline August 23, 2002-November 22, 2002 & 1,289 & 36.3 & 14.7 & 12.0 & 12.7 & 0.5 & 6.0 & 19.0 & 140.0 & 0.1 \\
\hline May 23, 2002-August 22, 2002 & 1,330 & 36.2 & 14.5 & 11.3 & 12.7 & 0.5 & 6.0 & 19.0 & 140.0 & 0.1 \\
\hline February 23, 2002-May 22, 2002 & 1,325 & 36.0 & 14.5 & 11.0 & 12.7 & 0.4 & 6.0 & 18.8 & 140.0 & \\
\hline
\end{tabular}

Panel B

The 1,280 Firms that Declared Regular Dividends in All Seven Quarters

\begin{tabular}{|c|c|c|c|c|c|c|c|c|c|c|}
\hline Declaration Periods & $\mathbf{N}$ & Total \$ & Mean & Median & Std Dev & Min & $25^{\text {th }}$ & $75^{\text {th }}$ & Max & $\begin{array}{c}\text { Mean of } \\
\text { Within-Firm } \\
\text { Increases } \\
\end{array}$ \\
\hline August 23, 2003-November 22, 2003 & 1,280 & 40.6 & 16.0 & 13.0 & 13.0 & 0.5 & 7.5 & 20.0 & 145.0 & $0.3 *$ \\
\hline May 23, 2003-August 22, 2003 & 1,280 & 40.0 & 15.6 & 12.7 & 13.0 & 0.5 & 7.0 & 20.0 & 145.0 & $0.5 *$ \\
\hline February 23, 2003-May 22, 2003 & 1,280 & 37.5 & 15.1 & 12.0 & 12.7 & 0.5 & 6.8 & 20.0 & 145.0 & $0.2 *$ \\
\hline November 23, 2002-February 22, 2003 & 1,280 & 36.8 & 15.0 & 12.0 & 12.8 & 0.5 & 6.6 & 19.5 & 145.0 & $0.2 *$ \\
\hline August 23, 2002-November 22, 2002 & 1,280 & 36.3 & 14.7 & 12.0 & 12.7 & 0.5 & 6.3 & 19.0 & 140.0 & 0.1 \\
\hline May 23, 2002-August 22, 2002 & 1,280 & 35.9 & 14.6 & 11.7 & 12.7 & 0.5 & 6.1 & 19.0 & 140.0 & 0.1 \\
\hline February 23, 2002-May 22, 2002 & 1,280 & 35.6 & 14.5 & 11.3 & 12.7 & 0.4 & 6.0 & 19.0 & 140.0 & \\
\hline
\end{tabular}

* significant at the 0.001 level 
TABLE 3

Regression Analysis of the Change in Regular Dividends Following Enactment

This table reports dividend per share descriptive statistics for a sample of 1,463 U.S. firms, described in Table 1. The data sample consists of all corporations reported by CRSP as declaring a regular quarterly dividend between February 23, 2002 and November 22, 2003 that have available information on the following variables: DPS, EPS, $F C F$ and $M T B$. DPS is regular quarterly dividends per share as declared from $2 / 23 / 02$ to $11 / 22 / 03$. EPS is quarterly earnings per share as reported during the period, $11 / 22 / 01$ to $8 / 22 / 03$ (Compustat item 69). $\quad F C F$ is free cash flow reported during the period 11/22/01 to $8 / 22 / 03$, which is defined as cash and short-term securities (Compustat Item 36) less accounts payable (Compustat Item 46) less other current liabilities (Compustat 48) per share. MTB is the market to book ratio flow reported during the period 11/22/01 to 8/22/03, defined as the market value of equity (Compustat Item 14 x Compustat Item 61) scaled by net book value (Compustat Item 61). POST is a categorical variable that equals 1 if the special dividend was declared between 5/23/03 and 11/23/03; zero, otherwise.

Panel $A$

Descriptive Statistics $(\boldsymbol{n}=9171)$

\begin{tabular}{|l|r|r|r|r|r|r|r|}
\hline & Mean & Med & \multicolumn{1}{|c|}{ SD } & \multicolumn{1}{c|}{ Min } & \multicolumn{1}{c|}{ th $^{\text {th }}$} & 75th & \multicolumn{1}{c|}{ Max } \\
\hline $\boldsymbol{D P S}$ & 0.15 & 0.12 & 0.13 & 0.00 & 0.06 & 0.19 & 1.45 \\
\hline $\boldsymbol{E P S}$ & 0.39 & 0.35 & 0.74 & -41.31 & 0.19 & 0.55 & 10.14 \\
\hline $\boldsymbol{F C F}$ & -0.05 & -0.01 & 0.08 & -1.00 & -0.09 & -0.00 & 0.29 \\
\hline $\boldsymbol{M T B}$ & 2.23 & 1.82 & 12.64 & -741.57 & 1.32 & 2.55 & 367.31 \\
\hline $\boldsymbol{P O S T}$ & 0.30 & & & & & & \\
\hline
\end{tabular}

\section{Panel B}

Estimated Coefficient (p-value) from Regressions of the Regular Dividends Per Share Declared on a Categorical Variable Indicating a Quarter after Enactment of the 2003 Act (POST) and Control Variables for the Regular Dividends Declared from February 23, 2002 to November 22, 2003

\begin{tabular}{|c|c|c|c|c|c|c|}
\hline & & (1) & (2) & (3) & (4) & (5) \\
\hline & pred & OLS & Rank & OLS & Rank & Logit \\
\hline Intercept & & $0.127 * *$ & $3309.99 * *$ & $0.129 * *$ & $3102.29 * *$ & $1.821 * *$ \\
\hline$E P S$ & $(+)$ & $0.038 * *$ & $0.36^{* *}$ & $0.035 * *$ & $0.35 * *$ & $0.264 * *$ \\
\hline$F C F$ & $(+)$ & -0.086 & -0.15 & -0.009 & -0.14 & -0.012 \\
\hline MTB & $(-)$ & -0.000 & 0.06 & -0.000 & 0.05 & 0.002 \\
\hline POST & $(+)$ & 0.005* & $124.95^{* *}$ & $0.009 * *$ & $202.61^{* * *}$ & $1.085^{* *}$ \\
\hline $\mathrm{n}$ & & 9,171 & 9,171 & 8,670 & 8,670 & 9,952 \\
\hline adjusted $R^{2}$ & & 0.05 & 0.18 & 0.05 & 0.17 & \\
\hline
\end{tabular}

*(**) significant at the $0.05(0.01)$ level

- Columns (1), (2) and (5) report results from estimates using the full sample of 1,463 firms that paid dividends during at least one quarter from February 23, 2002 to November 22, 2003.

- Columns (3) and (4) report results from estimates using the reduced sample of 1,280 firms that paid dividends every quarter from February 23, 2002 to November 22, 2003. 


\section{TABLE 4 \\ Statistical Information for the Regression Variables Testing a Link Between Dividend Increases and Individual Ownership}

This table reports descriptive statistics for a sample of 1,463 U.S. firms. The data sample consists of all corporations reported by CRSP as declaring a regular quarterly dividend between February 23, 2002 and November 22, 2003 that have available information on the following variables: $\triangle D I V, L A G \triangle D I V, \triangle E P S, I N D$, and INSIDE. $\triangle D I V$ is dividends per share as declared from 5/23/03 to 11/22/03 less dividends per share as declared from 11/23/02 to $5 / 22 / 03$. LAG $\triangle D I V$ is dividends per share as declared from $11 / 23 / 02$ to $5 / 22 / 03$ less dividends per share as declared from $5 / 23 / 02$ to $11 / 22 / 02$. $\triangle E P S$ is quarterly earnings per share as reported during the period, $11 / 23 / 02$ to $5 / 22 / 03$ less quarterly earnings per share as reported during the period, 5/23/02 to 11/22/02 (Compustat item 69). DYIELD is annualized dividends in two quarters preceding $5 / 23 / 03$, as a percentage of its share price on the declaration date. $I N D$ is one less the percentage of shares that are held by institutional investors as reported in 13-F filings and collected by CDA/Spectrum. INSIDE is the percentage of shares held by insiders as measured by holdings of officers and directors as reported in Thomson Financial's Insider Filing Data.

\section{Panel A: Descriptive Statistics}

\begin{tabular}{|l|c|c|r|r|r|r|r|r|}
\hline & $\mathbf{N}$ & Mean & Median & Std Dev & \multicolumn{1}{c|}{ Min } & 25 $^{\text {th }}$ & 75th & \multicolumn{1}{c|}{ Max } \\
\hline$\Delta \boldsymbol{D I V}$ & 1,463 & 0.022 & 0 & 0.068 & -0.850 & 0 & 0.020 & 0.730 \\
\hline $\boldsymbol{L A G} \Delta \boldsymbol{D I V}$ & 1,463 & 0.008 & 0 & 0.049 & -0.500 & 0 & 0.020 & 0.740 \\
\hline $\boldsymbol{\Delta E P S}$ & 1,463 & 0.092 & 0.030 & 1.031 & -15.010 & -0.100 & 0.190 & 16.990 \\
\hline $\boldsymbol{D Y I E L D}$ & 1,463 & 0.012 & 0.011 & 0.008 & 0 & 0.006 & 0.016 & 0.062 \\
\hline $\boldsymbol{I N D}$ & 1,463 & 0.542 & 0.525 & 0.292 & 0.008 & 0.285 & 0.825 & 1 \\
\hline $\boldsymbol{I N S I D E}$ & 1,463 & 0.071 & 0.026 & 0.116 & 0 & 0.006 & 0.081 & 0.834 \\
\hline
\end{tabular}

Panel B: Pearson's (Spearman's Rank) Correlation Coefficients over (under) the Diagonal (probability that the coefficient equals zero) for 1,463 observations

\begin{tabular}{|c|c|c|c|c|c|c|}
\hline & $\Delta D I V$ & $L A G \Delta D I V$ & $\triangle E P S$ & DYIELD & $I N D$ & INSIDE \\
\hline$\Delta D I V$ & 1.00 & 0.08 * & -0.00 & $-0.25 *$ & -0.06 & $0.07 *$ \\
\hline$L A G \Delta D I V$ & $0.24 *$ & 1.00 & 0.00 & 0.01 & 0.03 & 0.01 \\
\hline$\triangle E P S$ & $0.08 *$ & 0.04 & 1.00 & -0.01 & -0.06 & $-0.08 *$ \\
\hline DYIELD & $-0.25 *$ & $0.12 *$ & -0.03 & 1.00 & $0.22 *$ & $-0.07 *$ \\
\hline$I N D$ & 0.00 & $0.12 *$ & -0.02 & $0.27 *$ & 1.00 & $0.28 *$ \\
\hline INSIDE & 0.06 & $0.08 *$ & 0.03 & $-0.07 *$ & $0.35 *$ & 1.00 \\
\hline
\end{tabular}

* significant at the 0.01 level 
TABLE 5

\section{Estimated Coefficient ( $t$-statistic) from Regressions of the Change in Regular Quarterly Dividends Per Share Declared ( $\triangle D I V$ ) on Individual (IND) and Insider (INSIDE) Ownership of Stocks and Control Variables}

This table reports multivariate analyses for a sample of 1,463 U.S. firms. The data sample consists of all corporations reported by CRSP as declaring a regular quarterly dividend between February 23, 2002 and November 22, 2003 that have available information on the following variables: $\triangle D I V, L A G \triangle D I V, \triangle E P S, I N D$, and INSIDE. $\triangle D I V$ is dividends per share as declared from $5 / 23 / 03$ to $11 / 22 / 03$ less dividends per share as declared from 11/23/02 to $5 / 22 / 03$. $L A G \triangle D I V$ is dividends per share as declared from $11 / 23 / 02$ to $5 / 22 / 03$ less dividends per share as declared from $5 / 23 / 02$ to $11 / 22 / 02$. $\triangle E P S$ is quarterly earnings per share as reported during the period, $11 / 23 / 02$ to $5 / 22 / 03$ less quarterly earnings per share as reported during the period, 5/23/02 to 11/22/02 (Compustat item 69). DYIELD is annualized dividends in two quarters preceding $5 / 23 / 03$, as a percentage of its share price on the declaration date. IND is one less the percentage of shares that are held by institutional investors as reported in 13-F filings and collected by CDA/Spectrum. INSIDE is the percentage of shares held by insiders as measured by holdings of officers and directors as reported in Thomson Financial's Insider Filing Data.

\begin{tabular}{|l|c|c|c|c|}
\hline & & $(\mathbf{1})$ & $(\mathbf{2})$ & $\mathbf{( 3 )}$ \\
\hline Intercept & & 0.046 & 0.043 & 0.045 \\
& & $(11.5)$ & $(13.4)$ & $(11.2)$ \\
\hline LAG $\boldsymbol{A D I V}$ & & 0.114 & 0.113 & 0.115 \\
& & $(3.3)$ & $(3.3)$ & $(3.3)$ \\
\hline UEPS & & 0.000 & -0.000 & -0.000 \\
& & $(-0.3)$ & $(-0.1)$ & $(-0.1)$ \\
\hline DYIELD & & -2.000 & -1.988 & -1.935 \\
& & $(-9.7)$ & $(-9.8)$ & $(-9.3)$ \\
\hline IND & $(+)$ & $\mathbf{- 0 . 0 0 2}$ & & $\mathbf{- 0 . 0 0 7}$ \\
& & $\mathbf{( - 0 . 4 )}$ & & $\mathbf{( - 1 . 0 )}$ \\
\hline INSIDE & $\mathbf{( + )}$ & & $\mathbf{0 . 0 3 1}$ & $\mathbf{0 . 0 3 6}$ \\
& & & $(\mathbf{2 . 1})$ & $(\mathbf{2 . 3})$ \\
\hline adjusted R & & 0.07 & 0.07 & 0.07 \\
\hline
\end{tabular}


TABLE 6

Estimated Coefficient ( $t$-statistic) from Regressions of the Change in Regular Quarterly Dividends Per Share Declared ( $\triangle D I V)$ on Individual (IND) and Insider (INSIDE) Ownership of Stocks and Control Variables Under Various Specifications of the

\section{Pre- and Post-Enactment Quarters}

This table reports multivariate analyses for a sample of 1,463 U.S. firms. The data sample consists of all corporations reported by CRSP as declaring a regular quarterly dividend between February 23, 2002 and November 22, 2003 that have available information on the following variables: $\triangle D I V, L A G \triangle D I V, \triangle E P S, I N D$, and INSIDE. $\triangle D I V$ and $L A G \triangle D I V$ are defined below. $\triangle E P S$ is quarterly earnings per share over the same period as $L A G \triangle D I V$. DYIELD is annualized dividends in two quarters preceding 5/23/03, as a percentage of its share price on the declaration date. IND is one less the percentage of shares that are held by institutional investors as reported in 13-F filings and collected by CDA/Spectrum. INSIDE is the percentage of shares held by insiders as measured by holdings of officers and directors as reported in Thomson Financial's Insider Filing Data.

\begin{tabular}{|c|c|c|c|c|c|c|c|}
\hline & & (1) & (2) & (3) & (4) & (5) & (6) \\
\hline $\begin{array}{l}\text { Define: } \\
\Delta D I V\end{array}$ & & $\begin{array}{c}5 / 23 / 03-8 / 22 / 03 \\
\text { less } \\
2 / 23 / 03-5 / 22 / 03\end{array}$ & $\begin{array}{c}5 / 23 / 03-8 / 22 / 03 \\
\text { less } \\
5 / 23 / 02-8 / 22 / 03\end{array}$ & $\begin{array}{c}5 / 23 / 03-11 / 22 / 03 \\
\text { less } \\
5 / 23 / 02-11 / 22 / 02\end{array}$ & $\begin{array}{c}8 / 23 / 03-11 / 22 / 03 \\
\text { less } \\
5 / 23 / 03-8 / 22 / 03\end{array}$ & $\begin{array}{c}8 / 23 / 03-11 / 22 / 03 \\
\text { less } \\
8 / 23 / 02-11 / 22 / 02\end{array}$ & $\begin{array}{c}8 / 23 / 03-11 / 22 / 03 \\
\text { less } \\
2 / 23 / 03-5 / 22 / 03\end{array}$ \\
\hline $\begin{array}{l}\text { Define: } \\
L A G \Delta D I V\end{array}$ & & $\begin{array}{c}2 / 23 / 03-5 / 22 / 03 \\
\text { less } \\
11 / 23 / 02-2 / 22 / 03\end{array}$ & $\begin{array}{c}2 / 23 / 03-5 / 22 / 03 \\
\text { less } \\
2 / 23 / 02-5 / 22 / 03\end{array}$ & $\begin{array}{c}11 / 23 / 02-5 / 22 / 03 \\
\text { less } \\
11 / 23 / 01-5 / 22 / 02\end{array}$ & $\begin{array}{c}5 / 23 / 03-8 / 22 / 03 \\
\text { less } \\
2 / 23 / 03-5 / 22 / 03 \\
\end{array}$ & $\begin{array}{c}5 / 23 / 03-8 / 22 / 03 \\
\text { less } \\
5 / 23 / 02-8 / 22 / 02 \\
\end{array}$ & $\begin{array}{c}2 / 23 / 03-5 / 22 / 03 \\
\text { less } \\
8 / 23 / 02-11 / 22 / 02 \\
\end{array}$ \\
\hline IND & $(+)$ & $\begin{array}{c}-0.002 \\
(-0.6)\end{array}$ & $\begin{array}{l}-0.002 \\
(-0.8)\end{array}$ & $\begin{array}{l}-0.007 \\
(-0.9)\end{array}$ & $\begin{array}{c}-0.000 \\
(-0.0)\end{array}$ & $\begin{array}{c}-0.003 \\
(-0.9)\end{array}$ & $\begin{array}{l}-0.005 \\
(-1.5)\end{array}$ \\
\hline INS & $(+)$ & $\begin{array}{r}0.005 \\
(0.8) \\
\end{array}$ & $\begin{array}{r}0.004 \\
(0.5) \\
\end{array}$ & $\begin{array}{r}0.017 \\
(1.0) \\
\end{array}$ & \begin{tabular}{|c|}
0.014 \\
$(1.8)$ \\
\end{tabular} & $\begin{array}{c}0.011 \\
(1.3)\end{array}$ & $\begin{array}{c}0.028 \\
(3.3) \\
\end{array}$ \\
\hline
\end{tabular}


TABLE 7

Summary Statistics for the 84 Special Dividends Declared by 62 Firms from February 23, 2002 to November 22,2003

This table reports dividend descriptive statistics, expressed in cents, for a sample of 62 U.S. firms. The data sample consists of all corporations reported by CRSP as declaring a special dividend between February 23, 2002 and November 22, 2003.

\begin{tabular}{|c|c|c|c|c|c|c|c|c|c|}
\hline Declaration Periods & Obs $>0$ & Total \$ billions & Mean & Median & Std Dev & Min & $25^{\text {th }}$ & $75^{\text {th }}$ & Max \\
\hline August 23, 2003-November 22, 2003 & 31 & 0.644 & 51 & 25 & 78 & 1 & 10 & 68 & 400 \\
\hline May 23, 2003-August 22, 2003 & 22 & 0.555 & 81 & 28 & 115 & 2 & 10 & 100 & 500 \\
\hline February 23, 2003-May 22, 2003 & 8 & 0.230 & 71 & 53 & 86 & 4 & 5 & 100 & 250 \\
\hline November 23, 2002-February 22, 2003 & 2 & 0.001 & 20 & 20 & 0 & 20 & 20 & 20 & 020 \\
\hline August 23, 2002-November 22, 2002 & 14 & 0.161 & 44 & 17 & 62 & 2 & 5 & 36 & 200 \\
\hline May 23, 2002-August 22, 2002 & 6 & 0.003 & 17 & 5 & 22 & 2 & 3 & 30 & 56 \\
\hline February 23, 2002-May 22, 2002 & 1 & 0.000 & 10 & 10 & 0 & 10 & 10 & 10 & 10 \\
\hline
\end{tabular}


TABLE 8

\section{Regression Analysis of the Change in Special Dividends Following Enactment}

This table reports descriptive statistics for a sample of 62 U.S. firms. The data sample consists of all corporations reported by CRSP as declaring a special dividend between February 23, 2002 and November 22, 2003 that have available information on the following variables: $S D, E P S, F C F$ and $M T B . S D$ is dividends per share as declared from $2 / 23 / 02$ to $11 / 22 / 03$. EPS is quarterly earnings per share as reported during the period, $11 / 22 / 01$ to $8 / 22 / 03$ (Compustat item 69). FCF is free cash flow reported during the period 11/22/01 to 8/22/03, which is defined as cash and short-term securities (Compustat Item 36) less accounts payable (Compustat Item 46) less other current liabilities (Compustat 48) per share. MTB is the market to book ratio flow reported during the period 11/22/01 to $8 / 22 / 03$, defined as the market value of equity (Compustat Item 14 x Compustat Item 61) scaled by net book value (Compustat Item 61). POST is a categorical variable that equals 1 if the special dividend was declared between 5/23/03 and 11/23/03; zero, otherwise.

Panel A: Descriptive Statistics $(n=82)$

\begin{tabular}{|l|r|r|r|r|r|r|r|}
\hline & Mean & Med & S D & Min & 25 $^{\text {th }}$ & 75th $^{\text {Max }}$ \\
\hline SD & 0.57 & 0.25 & 0.86 & 0.01 & 0.07 & 1.00 & 5.00 \\
\hline $\boldsymbol{E P S}$ & 0.31 & 0.32 & 0.29 & -0.23 & 0.12 & 0.42 & 1.52 \\
\hline $\boldsymbol{F C F}$ & -0.44 & -0.05 & 0.75 & -4.86 & -0.75 & 0.00 & 0.29 \\
\hline $\boldsymbol{M T B}$ & 1.75 & 1.59 & 0.94 & 0.61 & 1.15 & 1.97 & 6.99 \\
\hline $\boldsymbol{P O S T}$ & 0.63 & & & & & & \\
\hline
\end{tabular}

Panel B: Estimated Coefficient (p-value) from Regressions of the Special Dividends Per Share Declared on a Categorical

Variable Indicating a Quarter after Enactment of the 2003 Act (POST) and Control Variables for the 82 Special Dividends Declared from February 23, 2002 to November 22, 2003

\begin{tabular}{|l|c|c|c|}
\hline & Logit & OLS & Rank \\
\hline Intercept & -2.42 & 1.00 & 33.44 \\
& $(0.01)$ & $(0.01)$ & $(0.01)$ \\
\hline EPS & 0.90 & -0.36 & 0.07 \\
& $(0.03)$ & $(0.87)$ & $(0.27)$ \\
\hline FCF & -0.09 & 0.23 & 0.33 \\
& $(0.69)$ & $(0.04)$ & $(0.01)$ \\
\hline MTB & -0.05 & -0.19 & -0.32 \\
& $(0.34)$ & $(0.03)$ & $(0.01)$ \\
\hline POST & $\mathbf{1 . 9 5}$ & $\mathbf{0 . 1 8}$ & $\mathbf{7 . 5 5}$ \\
& $(\mathbf{0 . 0 1 )}$ & $(\mathbf{0 . 1 8})$ & $(\mathbf{0 . 0 7})$ \\
\hline $\mathbf{n}$ & 422 & 82 & 82 \\
\hline adjusted R & & 0.08 & 0.20 \\
\hline
\end{tabular}


TABLE 9

Individual and Insider Ownership of the Firms Paying Special Dividends

This table reports individual and insider holdings for a sample of 62 U.S. firms. The data sample consists of all corporations reported by CRSP as declaring a special dividend between February 23, 2002 and November 22, 2003. IND is one less the percentage of shares that are held by institutional investors as reported in 13-F filings and collected by CDA/Spectrum. INSIDE is the percentage of shares held by insiders as measured by holdings of officers and directors as reported in Thomson Financial's Insider Filing Data.

Panel A: Individual Ownership (IND) of Firms Paying Special Dividends (n=84)

\begin{tabular}{|l|c|c|c|c|c|c|c|c|}
\hline \multicolumn{1}{|c|}{ Declaration Periods } & Obs & Mean & Median & Std Dev & Min & $\mathbf{2 5}^{\text {th }}$ & $\mathbf{7 5}^{\text {th }}$ & $\mathbf{M a x}$ \\
\hline August 23, 2003-November 22, 2003 & 31 & 0.79 & 0.84 & 0.22 & 0.29 & 0.72 & 0.96 & 1 \\
\hline May 23, 2003-August 22, 2003 & 22 & 0.75 & 0.78 & 0.20 & 0.17 & 0.64 & 0.89 & 1 \\
\hline February 23, 2002-May 22, 2003 & 31 & 0.86 & 0.88 & 0.14 & 0.51 & 0.75 & 0.98 & 1 \\
\hline & & & & & & & & \\
\hline IND for firms paying regular quarterly dividends & 1,463 & 0.54 & 0.52 & 0.29 & 0 & 0.29 & 0.82 & 1 \\
\hline
\end{tabular}

Panel B: Insider Ownership (INSIDE) of Firms Paying Special Dividends (n=84)

\begin{tabular}{|l|c|c|c|c|c|c|c|c|}
\hline \multicolumn{1}{|c|}{ Declaration Periods } & Obs & Mean & Median & Std Dev & Min $^{\text {th }}$ & $\mathbf{7 5}^{\text {th }}$ & Max \\
\hline August 23, 2003-November 22, 2003 & 31 & 0.12 & 0.11 & 0.12 & 0 & 0.02 & 0.17 & 0.53 \\
\hline May 23, 2003-August 22, 2003 & 22 & 0.15 & 0.08 & 0.20 & 0 & 0.02 & 0.17 & 0.68 \\
\hline February 23, 2002-May 22, 2003 & 31 & 0.11 & 0.03 & 0.15 & 0 & 0.01 & 0.12 & 0.59 \\
\hline & & & & & & & & \\
\hline INSIDE for firms paying regular quarterly dividends & 1,463 & 0.07 & 0.03 & 0.12 & 0 & 0.01 & 0.08 & 0.83 \\
\hline
\end{tabular}

